\title{
Temporal surveys of French populations of Drosophila melanogaster: $P-M$ system, enzymatic polymorphism and infection by the sigma virus
}

\author{
D. Anxolabéhère*, \\ L. Charles-Palabost, $\dagger$ \\ A. Fleuriet $\ddagger$ and \\ G. Periquet $\dagger$
}

\author{
* Mécanismes moléculaires de la spéciation, \\ Université P. \& M. Curie, 4 place Jussieu, \\ 75005 Paris, France. \\ † Institut de Biocénotique Expérimentale des \\ Agrosystèmes, Faculté des Sciences, Parc Grandmont, \\ 37200 Tours, France. \\ † Laboratoire de Génétique, Université de Clermont \\ Ferrand II, B.P. 45, 63170 Aubière, France.
}

\begin{abstract}
About 120 strains derived from natural populations of $D$. melanogaster collected between 1983 and 1986 in the Languedoc-Roussillon area (France) were tested for their characteristics in the $\boldsymbol{P}-\boldsymbol{M}$ system, enzymatic polymorphism and infection by the sigma virus. Over these four years, a clear geographical pattern was found for the $P$ - $M$ system over a distance of $250 \mathrm{~km}$, with weak $P$ populations in the northern zone of the area studied, $Q$ populations in the centre and $\boldsymbol{M}^{\prime}$ populations in the south. This pattern was stable for $P$ sterility potential but a decrease of the $M$ cytotype level was observed in the southernmost zone. During the same period, the frequency of flies infected by the sigma virus also showed a regular geographical pattern with the highest values in the central zone. The frequency of infected flies increased steadily during this period. In the enzymatic study, neither geographical nor temporal trends were detected for the loci analyzed. Correlations among the different systems are discussed.
\end{abstract}

\section{INTRODUCTION}

Over the last decade, several studies of genetic variation in natural Drosophila populations have involved non-Mendelian systems. In $D$. melanogaster, such studies have centred on the $P-M$ system of transposable elements (see Bregliano and Kidwell, 1983 and Engels, 1983) and on the vertically transmitted sigma virus (L'Héritier, 1970; Brun and Plus, 1980). There is a geographical variation in the distribution of both systems in Europe. The pattern of this variation points to the Languedoc-Roussillon, a region in the south of France, as an intermediate zone of special interest for evolutionary studies (Anxolabéhère et al., 1985; Fleuriet, 1986).

In the $P-M$ system of Drosophila melanogaster, the syndrome known as hybrid dysgenesis occurs when members of the $P$ family of transposable elements are activated. It is manifested in a number of traits (such as mutation, male recombination and gonadal sterility) when active $P$ elements are introduced into the $M$ cytotype individuals (Engels, 1979; Kidwell, 1985). These are defined as either completely lacking $P$ sequences ( $M$-type) or containing structurally altered $P$ elements $\left(M^{\prime}\right.$ type) (Bingham et al., 1982). In contrast, individuals of the $P$ type or of the $Q$ type (which induce all dysgenic traits except sterility) have 30-50 copies of $P$ sequences (Bingham et al., 1982), some of which are fully intact elements, $2.9 \mathrm{~kb}$ long, that can code for a transposase (Karess and Rubin, 1984) and the others, often a majority, are deleted $P$ elements that, in dysgenic crosses, can be mobilized in response to the transposase produced by intact elements of the same genome (O'Hare and Rubin, 1983). $P$ and $Q$ individuals also possess a cellular state called the $P$ cytotype which represses $P$ element activity (Engels, 1979; Simmons and Bucholz, 1985).

Surveys of natural populations have shown pronounced geographical differences (Anxolabéhère et al., 1982, 1984; Kidwell, 1983; Boussy and Kidwell, 1987). $P$ strains predominate in the Americas and Central Africa whereas $M$ cytotype strains predominate in Europe, North Africa and Asia. Recent investigations (Anxolabéhère et al., 1985) reveal a gradient from Western Europe, where 
most strains are $Q$, to Mid-Asian areas, where $M^{\prime}$ strains predominate. These results concur with the hypothesis of an invasion of Eurasian populations by $P$ elements.

In the Drosophila-sigma system, the virus confers $\mathrm{CO}_{2}$ sensitivity on its carriers; the sigma virus is not contagious but is transmitted from fly to fly through gametes without being integrated into the chromosomes (Brun and Plus, 1980). In natural French populations of D. melanogaster, about 20 per cent of the individuals are infected by sigma. In France, the characteristics of the system differ from those observed in the rest of Europe (Fleuriet, 1986).

This paper focuses on a review of the Languedoc-Roussillon area, a region of transition from $P-Q$ to $M$ cytotype populations and sigma virus characteristics, over four consecutive years. We examine for pattern modifications in this transition area, as well as possible correlations between the geographical patterns of the $P-M$ system and of sigma virus. Populations of this region were also characterized for their polymorphism at six enzymatic loci.

\section{MATERIALS AND METHODS}

More than 100 wild samples, collected in the Languedoc-Roussillon region over a $250 \mathrm{~km} \times$ $50 \mathrm{~km}$ area (fig. 1) were investigated. Each consisted of a large number of flies (from 60 to 250) collected in October 1983, 1984, 1985 and 1986.

\section{Analysis of the P-M system}

Determination of $\mathrm{P}-\mathrm{M}$ status within a population. Following the procedures of Periquet (1980) $P$ potential activity was measured at $28 \cdot 5^{\circ} \mathrm{C}$ by determining the percentage of dysgenic gonads ( $G D$ sterility) in $50 \mathrm{~F} 1$ females resulting from a cross between females from the Canton-S reference strain and males from the tested strain (Cross A). $M$ cytotype level was measured at $28 \cdot 5^{\circ} \mathrm{C}$ by determining the percentage of dysgenic gonads in 50 F1 females resulting from a cross between males from the Harwich reference strain and females from the strain being tested (Cross $A^{*}$ ).

Hybridization techniques. The presence of $P$ homologous sequences in individual flies was detected by the squash-blot technique (Tchen et al., 1985; Anxolabéhère et al., 1985). Each fly was crushed on a nylon filter membrane (Pall Biodyne) and the DNA fixed on the filter was denatured in

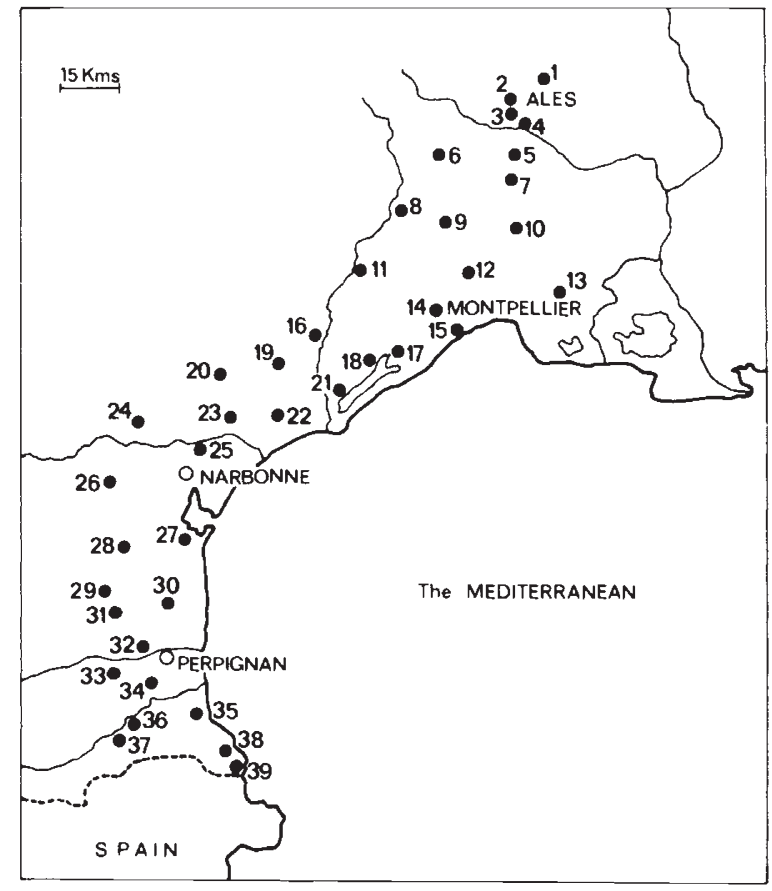

Figure 1 Geographical location of the D. melanogaster populations sampled in the Languedoc-Roussillon area from 1983 to 1986. 1. Les Fumades, 2. Alès, 3. Vermeil, 4. Vézénobres, 5. Ledignan, 6. St Hippolyte, 7. Crespian, 8. St Martin de Londres, 9. St Mathieu, 10. Boisseron, 11. Aniane, 12. Vendargues, 13. St Laurent, 14. Montpellier, 15. Perols, 16. Paulhan, 17. Gigean, 18. Mèze, 19. Servian, 20. Cazouls, 21. Marseillan, 22. Cers, 23. Nissan, 24. Ventenac, 25. Coursan, 26. Ferrals, 27. Sigean, 28. Durban, 29. Tuchan, 30. Salses, 31. Tautavel, 32. Rivesaltes, 33. Thuir, 34. Bages, 35. Argelès, 36. Le Boulou, 37. Aubiry, 38. Banyuls, 39. Cerbère.

$0 \cdot 5 \mathrm{~N} \mathrm{NaOH}-2 \cdot 5 \mathrm{M} \quad \mathrm{NaCl}$, neutralised in $3 \mathrm{M} \mathrm{NaCH} \mathrm{COO}_{3} \mathrm{CO}$, prehybridized in $2 \times \mathrm{SSC}-5 \times$ FPG solution for two hours and hybridized overnight at $65^{\circ} \mathrm{C}$ in $2 \times \mathrm{SCC}-1 \times \mathrm{FPT}$ and 10 per cent dextran sufate solution with ${ }^{32} \mathrm{P}$ labelled Hind III restriction fragment ( $P_{1}$ probe), or with labelled Hind III-Sal I restriction fragment $\left(P_{2}\right.$ probe $)$ of the $\mathrm{p} \pi 25 \cdot 1$ plasmid. After hybridization, the filter was washed for one hour at $65^{\circ} \mathrm{C}$ in $2 \times \mathrm{SSC}, 0 \cdot 1$ per cent SDS and then rapidly at room temperature in $0 \cdot 1 \times \mathrm{SSC}, 0 \cdot 1$ per cent SDS.

\section{Analysis of enzymatic polymorphism}

Allozyme variation was studied by starch gel electrophoresis using the techniques described by Charles-Palabost et al. (1986). Six polymorphic enzyme loci were analyzed: Acph (acid phosphatase; 3-101.4), Adh (alchol dehydrogenase; 
2-50.1), Est-C (esterase-C; 3-47.6), Est-6 (esterase-6; 3-36.8), $\alpha$-Gpdh ( $\alpha$-glycerophosphate dehydrogenase; 2-20.5) and Pgm (phosphoglucomutase; 3-43.4).

\section{Analysis of the Drosophila-sigma system}

The frequency of flies infected by the sigma virus was estimated for each sample by standard $\mathrm{CO}_{2}$ sensitivity tests (Plus, 1954), performed on about 50 adults collected in the wild.
RESULTS

\section{The $P-M$ system}

Fig. 2 presents the $P-M$ status of collected strains, tested for their induced GD sterility when crossed with Harwich and Canton S. Spearman rank correlation tests clearly show the existence of a latitudinal variation. For each of the four years studied, both $P$ sterility potential and $M$ cytotype level are significantly correlated with populations ranked from North to South (the eighty coefficients
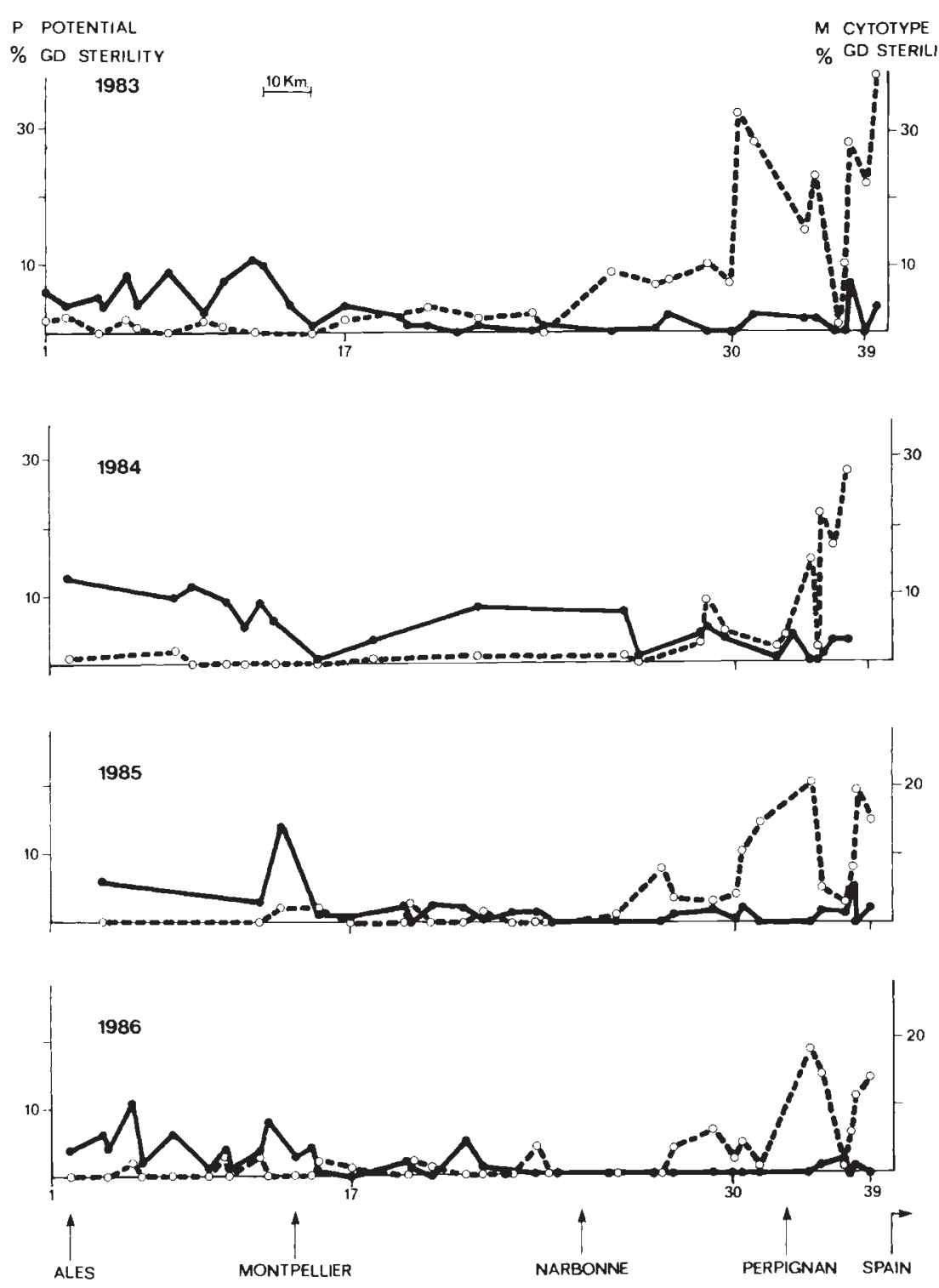

Figure 2 Geographical and temporal distributions of strains collected in Languedoc-Roussillon according to their potential for the $P-M$ system. Solid lines $=P$ potential activity; dashed lines $=M$ cytotype level. 
are within the interval $0 \cdot 34-0 \cdot 79$ and all are significant with $P<0.05$ to $P<0.001)$. There is a marked difference between the northern $P$ cytotype populations and the southern populations with intermediate levels of $M$ cytotype, a pattern clearly paralleled by the significantly higher $P$ sterility potential of northern strains as compared to southern strains.

To differentiate this pattern, multivariate analyses were performed by component analyses. Two principal components emerged. The first is associated with the cytotype and differentiates $P$ from $M$ cytotype strains, while the second is associated with $P$ potential activity and differentiates $P$ from $Q$ strains. These components explain 83-92 per cent of the total geographic variation, depending on the year observed. Consequently three zones can be defined (table 1). Zone A, the northernmost, from Les Fumades (1) to Gigean (17) has the highest $P$ sterility potential (with a mean of $5 \cdot 4$ per cent over the four year period) and the lowest $M$ cytotype level $(0.7$ per cent $)$. Zone B, the central zone from Mèze (18) to Salses (30) has very low values of both $P$ potential $(1.3$ per cent $)$ and $M$ cytotype level $(2 \cdot 4$ per cent). Zone C, the southernmost, from Tautavel (31) to Cerbère (39) has low $P$ potential $(1.5$ per cent $)$ and the highest $M$ cytotype level $(13.7$ per cent). There is a spacecontinuum in this area over a distance of $250 \mathrm{~km}$, with weak $P$ populations in the north, $Q$ in the centre and moderate $M$ cytotype population in the south.

No significant temporal trends over the four years were shown for the $P$ sterility potential in any zone of the whole area (Table 1). For the $M$ cytotype level, no variations were found for the northern and central zones. However, significant differences were observed in the southern zone which showed a slight decrease of the $M$ cytotype level (Spearman $\rho=0 \cdot 36, P=0 \cdot 02$ ). Thus if weak
$P$ and $Q$ populations appear to be stable in the northern and central zones, a slow change might be occuring in the south, leading to $Q$ strains. However this trend is slight and one must wait for new collections in the future to see if there is a real increase in the number of $P$ elements in southern populations.

In other European populations, $P$ homologous sequences have been found in strains with intermediate values of $M$ cytotype potential (Anxolabéhère et al., 1985). In the LanguedocRoussillon area, direct hybridizations with $P_{1}$ and $P_{2}$ probes on 22 strains, selected at random from the 1984 and 1985 sets, again demonstrated the presence of $P$ homologues in all the individuals tested. All these $M$ cytotype populations are of the $M^{\prime}$ type. Moreover, there were no significant differences in intensity of the hybridization signals between northern and southern populations, a fact that indicates a roughly similar number of homogologous sequences among these strains (Tchen et al., 1985, Ronsseray, personal communication). The geographical variation in $P-M$ status of these populations hence suggests that they mainly differ in the types of complete and deleted $P$ sequences they contain, rather than in the total number of $P$ elements.

The question of temporal variation of this distribution before this four year study remains open. However, the Languedoc-Roussillon area is of special interest in testing long trends, as it was one of the first regions to be sampled and surveyed in Europe. Old stocks available from this area and maintained in different laboratories, were used in order to trace back the evolution of the $P-M$ system. Although inbreeding, selection and drift in the laboratory mean that present frequencies have no chance of accurately representing the state of a population sampled ten or more years ago, it is still possible to test for the presence or absence

Table 1 Phenotypic characteristics of strains collected in the Languedoc-Roussillon area from 1983 to 1986, classified in three latitudinal zones

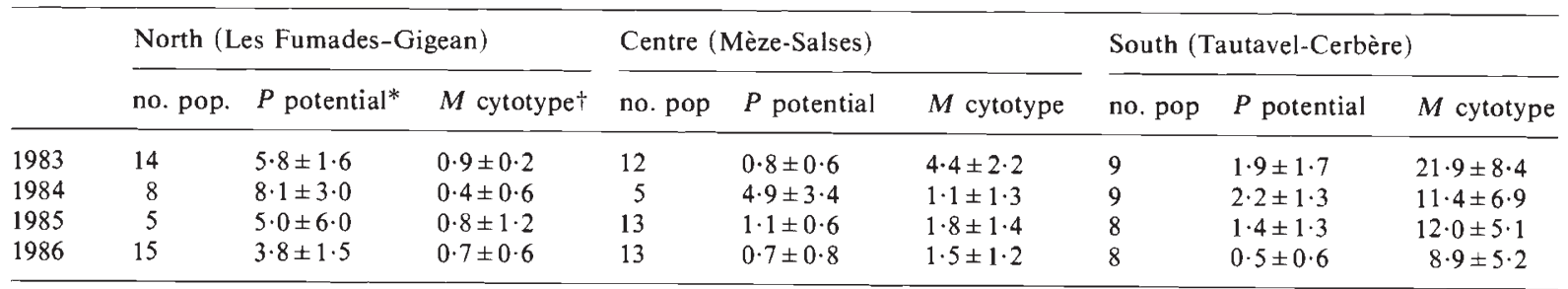

* $P$ potential is the mean of $P$ sterility potential of all strains tested in each zone and measured by per cent GD sterility in diagnostic cross A.

$\dagger M$ cytotype is the mean of $M$ cytotype level of all strains tested in each zone and measured by per cent GD sterility in diagnostic cross $A^{*}$.

Each mean is given with its confidence interval at 5 per cent. 
of $P$ homologous sequences (table 2 and fig. 3 ). Although the number of available strains was not very high, the overall data are coherent. From 1938 until 1967, all the strains tested were of the true $M$ type, with an $M$ cytotype and absolutely no $P$ homologous sequences. This is also true for the Marseillan 65 strain which contains the "atrophie gonadique" character (Periquet, 1980). When raised at $28^{\circ} \mathrm{C}$, these agametic mutants show high levels of intrastrain sterility very similar to the GD sterility induced in the $P-M$ system. One hypothesis suggests that this strain is polytypic, with $M$ cytotype and $P$ elements (Periquet, 1980; Engels and Preston, 1980). However, none of the direct hybridization experiments detected the presence of $P$ sequences, even in three sib-mating lines selected for high level of "ag" sterility. Thus, the

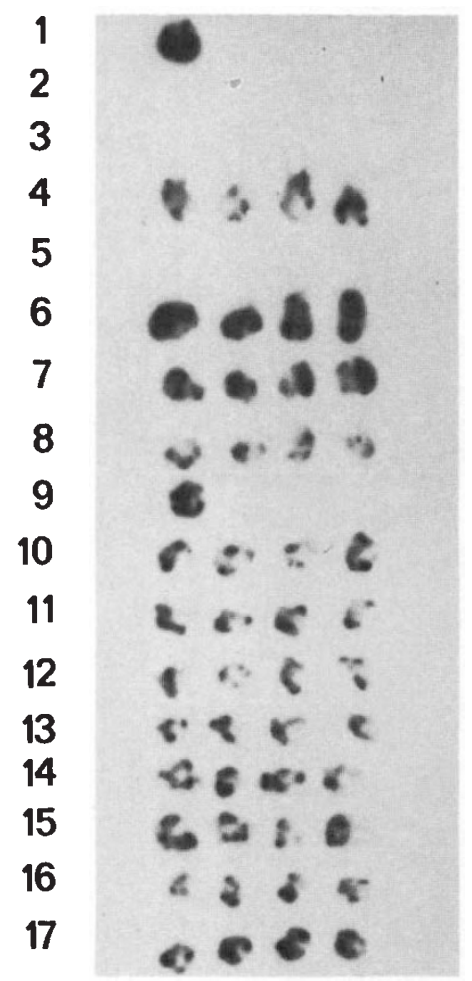

Figure 3 Examples of the responses to direct hybridization with the $P_{1}$ probe. Three levels of signal intensity are recognized: $\mathrm{S}=$ strong; $\mathrm{I}=$ intermediate; $-=$ null. Four individuals were taken from each laboratory strain originating from the Languedoc-Roussillon collection since 1938: 1. Controls (S - - ), 2. Banyuls $1938(-), 3$. Banyuls 1952 (-), 4. Control (I), 5. Marseillan 1965 (-), 6. Tautavel 1967 (S), 7. Mèze 1971 (S), 8. Mèze 1973 (1), 9. Controls (S - - ), 10. Mèze 1978 (I), 11. Marseillan 1978 (I), 12. Vermeil 1982 (I), 13. Tautavel 1982 (I), 14. Tautavel 1983 (I), 15. Mèze 1984 (I), 16. Tautavel 1985 (I), 17. Mèze 1986 (I). In each experiment, the control individuals are Harwich (S), Gruta (. - ) and Tostes (I).
Table 2 Phenotypic and molecular characteristics of strains collected in the Languedoc-Roussillon area between 1938 and 1986

\begin{tabular}{|c|c|c|c|c|c|}
\hline \multirow[b]{2}{*}{ Strain } & \multirow{2}{*}{$\begin{array}{l}\text { Collection } \\
\text { year }\end{array}$} & \multirow{2}{*}{$\begin{array}{l}P \\
\text { potential* }\end{array}$} & \multirow{2}{*}{$\begin{array}{l}M \\
\text { cytotype } \dagger\end{array}$} & \multicolumn{2}{|c|}{ Probe $\ddagger$} \\
\hline & & & & $P_{1}$ & $P_{2}$ \\
\hline Banyuls & 1938 & 0 & $99 \pm 2 \cdot 0$ & - & - \\
\hline Banyuls & 1952 & 0 & $94 \pm 4 \cdot 7$ & - & - \\
\hline Marseillan & 1965 & 0 & $90 \pm 5 \cdot 9$ & - & - \\
\hline Tautavel & 1967 & $2 \cdot 8 \pm 3 \cdot 2$ & $2 \pm 2 \cdot 7$ & $\mathrm{~S}$ & S \\
\hline Mèze & 1971 & $3 \cdot 6 \pm 3 \cdot 7$ & 0 & S & $\mathrm{S}$ \\
\hline Mèze & 1973 & 0 & $20 \pm 7 \cdot 8$ & I & I \\
\hline Mèze & 1978 & $1 \pm 2 \cdot 0$ & 0 & 1 & 1 \\
\hline Marseillan & 1978 & $2 \pm 2 \cdot 7$ & 0 & I & I \\
\hline Vermeil & 1982 & $4 \pm 3 \cdot 8$ & $4 \pm 3 \cdot 8$ & I & I \\
\hline Tautavel & 1982 & $1 \pm 2 \cdot 0$ & $37 \pm 9 \cdot 5$ & $\mathrm{I}$ & 1 \\
\hline Tautavel & 1983 & 0 & $32 \pm 9 \cdot 1$ & I & I \\
\hline Mèze & 1984 & $4 \pm 3 \cdot 8$ & $1 \pm 2 \cdot 0$ & I & I \\
\hline Tautavel & 1985 & $2 \pm 2 \cdot 7$ & $11 \pm 6 \cdot 1$ & I & 1 \\
\hline Mèze & 1986 & 0 & $2 \pm 2 \cdot 7$ & 1 & I \\
\hline
\end{tabular}

* $P$ activity potential was measured by per cent GD sterility in diagnostic cross A

$\dagger M$ cytotype was measured by per cent GD sterility in diagnostic cross $A^{*}$

$\ddagger$ Abbreviations for strength of hybridization to the probes are: $\mathrm{S}=$ strong; $\mathrm{I}=$ intermediate $; \quad-=$ hybridization completely undetectable.

"atrophie gonadique" character appears to be independent of $P$ sequences detected for the first time in French strains from the 1967 Tautavel population. Since that time, all strains originating from the study area, and in fact from any French population (Anxolabéhère et al., 1988), harbour $P$ sequences.

\section{Enzymatic polymorphism}

For 15 populations randomly selected among the 1983 strains, table 3 gives the number of flies analyzed and the allelic frequencies at the six loci studied. In order to determine the existence of a spatial variation in the frequencies of the six enzymatic loci, corresponding to the gradient observed in the $P-M$ system, statistical analyses were performed using the Spearman rank correlation test (table 3 ). None of the values were significantly different from zero and, if some geographical heterogeneity exists, it can be attributed mainly to local differences.

Keeping in mind the three zones defined for the $P-M$ system, an attempt was made to compare different levels of heterozygosity. The 15 populations form three groups: I with Les Fumades, Vermeil, Vézénobres, St Martin L, Vendargues and Paulhan; II with Mèze, Cazouls, Marseillan, 
Table 3 Allelic frequencies at 6 enzymatic loci in 15 strains collected in 1983 in the Languedoc-Roussillon area compared to other French populations

\begin{tabular}{|c|c|c|c|c|c|c|c|c|c|}
\hline \multirow[b]{2}{*}{ Strains } & \multicolumn{3}{|l|}{ Acph } & \multicolumn{3}{|l|}{$A d h$} & \multicolumn{3}{|c|}{ Est $-C$} \\
\hline & $n$ & $F$ & $S$ & $n$ & $F$ & $S$ & $n$ & $F$ & $S$ \\
\hline Les Fumades & 233 & 0.972 & 0.028 & 233 & 0.974 & 0.026 & 233 & 0.966 & 0.034 \\
\hline Vermeil & 162 & 0.972 & 0.028 & 162 & 0.929 & 0.071 & 163 & 0.945 & 0.055 \\
\hline Vézénobres & 166 & $1 \cdot 000$ & 0 & 166 & 0.979 & 0.021 & 165 & 0.967 & 0.033 \\
\hline St Martin L. & 152 & 0.980 & 0.020 & 164 & 0.936 & 0.064 & 164 & 0.924 & 0.076 \\
\hline Vendargues & 178 & 1.000 & 0 & 255 & 0.994 & 0.006 & 178 & 0.969 & 0.031 \\
\hline Paulhan & 130 & 0.996 & 0.004 & 136 & 0.967 & 0.033 & 135 & 0.956 & 0.044 \\
\hline Mèze & 202 & 1.000 & 0 & 216 & 0.984 & 0.016 & 217 & 0.889 & 0.111 \\
\hline Cazouls & 164 & 0.994 & 0.006 & 164 & 0.970 & 0.030 & 164 & 0.927 & 0.073 \\
\hline Marseillan & 94 & $1 \cdot 000$ & 0 & 149 & 0.990 & 0.010 & 94 & 0.973 & 0.027 \\
\hline Ferrals & 141 & 0.993 & 0.007 & 153 & 0.993 & 0.007 & 151 & 0.940 & 0.060 \\
\hline Tuchan & 139 & 1.000 & 0 & 139 & 0.971 & 0.029 & 137 & 0.832 & $0 \cdot 168$ \\
\hline Tautavel & 108 & $1 \cdot 000$ & 0 & 107 & 0.977 & 0.023 & 108 & 0.931 & 0.069 \\
\hline Rivesaltes & 111 & 1.000 & 0 & 108 & 1.000 & 0 & 110 & 0.982 & 0.018 \\
\hline Le Boulou & 138 & 0.982 & 0.018 & 145 & 0.890 & $0 \cdot 110$ & 145 & 0.962 & 0.038 \\
\hline Banyuls & 141 & 0.979 & 0.021 & 141 & 0.918 & 0.082 & 104 & 0.971 & 0.029 \\
\hline$\Sigma \& \overline{\mathrm{x}}$ & 2259 & 0.990 & $0 \cdot 101$ & 2438 & 0.966 & 0.034 & 2268 & 0.940 & 0.060 \\
\hline Sperman's $\rho$ & \multicolumn{3}{|c|}{$0.218 \mathrm{NS}$} & \multicolumn{3}{|c|}{$0.046 \mathrm{NS}$} & \multicolumn{3}{|c|}{$0.129 \mathrm{NS}$} \\
\hline $\begin{array}{l}\text { Means of } 15 \text { populations } \\
\text { originating from } \\
\text { Saône et Rhône valleys* }\end{array}$ & \multicolumn{3}{|c|}{$0.991 \pm 0.002$} & \multicolumn{3}{|c|}{$0.959 \pm 0.005$} & \multicolumn{3}{|c|}{$0.883 \pm 0.009$} \\
\hline $\begin{array}{l}\text { Means of } 14 \text { populations } \\
\text { originating from different } \\
\text { regions of France } \dagger\end{array}$ & \multicolumn{3}{|c|}{$0.992 \pm 0.003$} & \multicolumn{3}{|c|}{$0.962 \pm 0.007$} & \multicolumn{3}{|c|}{$0.955 \pm 0.007$} \\
\hline
\end{tabular}

Ferrals and Tuchan; III with Tautavel, Rivesaltes, Le Boulou and Banyuls. Mean frequencies of heterozygotes observed were estimated for each locus separately $\left(H_{\mathrm{I}}\right)$ and for the whole set $\left(H_{i}\right)$. The analyses given in table 4 do not reveal any significant difference among the three groups for any of these parameters. For the loci tested, the enzymatic variability appears to be homogeneously distributed throughout the Languedoc-Roussillon. Since no temporal changes were detected in the enzymatic polymorphism of other French natural populations
(Charles-Palabost et al., 1985, 1986), no study was made over the following years.

\section{Drosophila-sigma system}

Fig. 4 shows the frequency of flies infected by the sigma virus within the populations sampled.

1983. The observed values range from 3 to 33 per cent and are not evenly distributed over the region examined. A striking increase is observed in samples from the central area, with values rising Table 4 Observed heterozygosity per locus $\left(H_{I}\right)$ and per individual $\left(\bar{H}_{i}\right)$, for strains collected in 1983 in the Languedoc-Roussillon
area and grouped according to their latitudinal origin

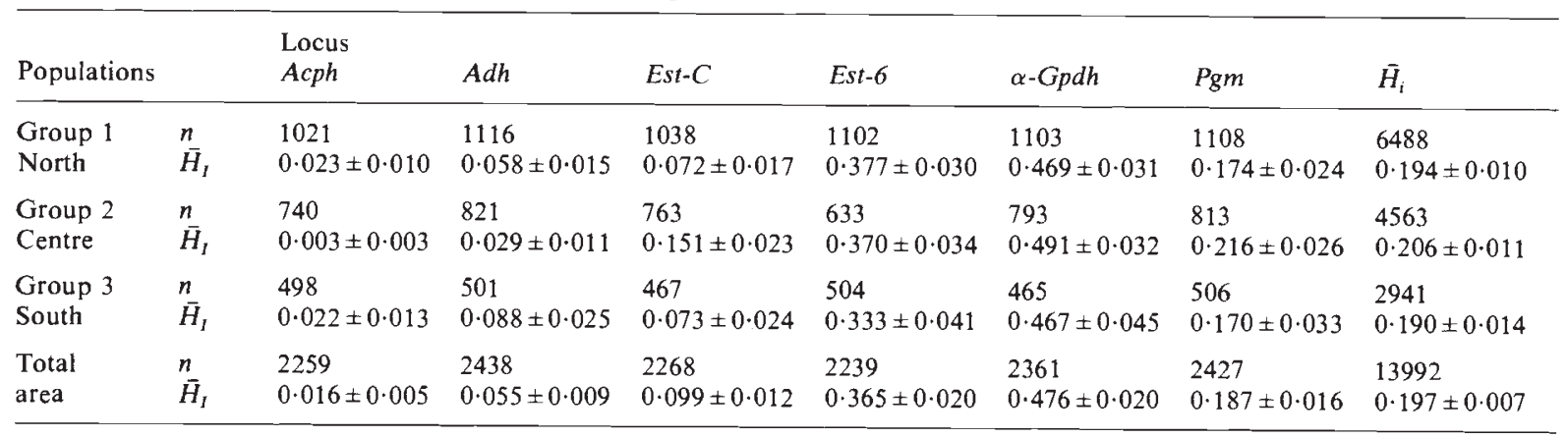




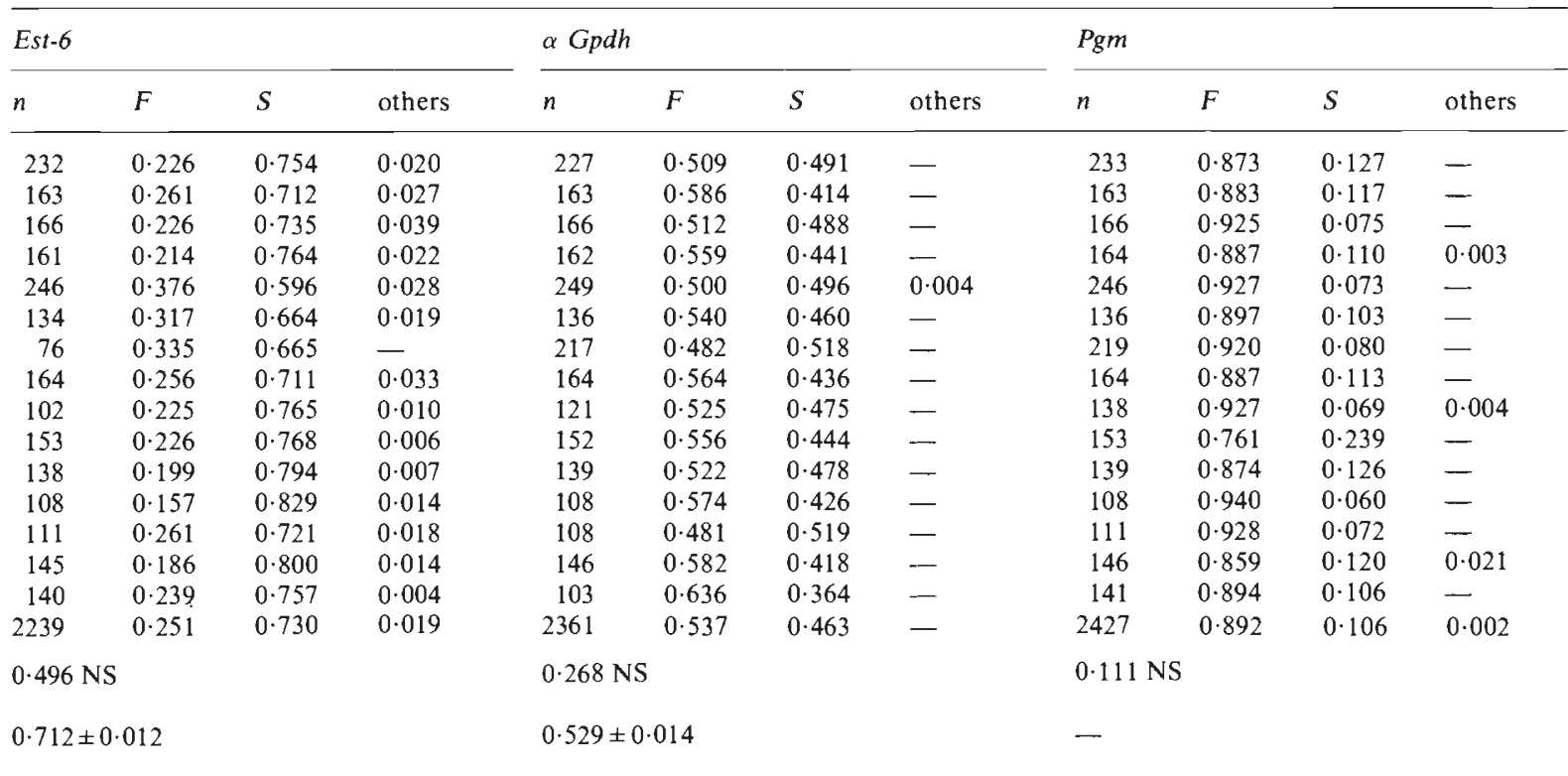

$n=$ number of flies analysed. $F, S$ and others = alleles.

$\rho=$ Spearman's rank correlation between each enzymatic system and the latitudinal origin of strains.

* from Girard and Palabost, 1976.

$\dagger$ from Charles-Palabost et al., 1985.

steadily to 33 per cent as compared to an average level of 10 per cent in the other regions. The populations may thus be distributed into three groups, the limits of which are not easy to determine precisely, covering, from north to south: (A) Les Fumades (1) to Gigean (17); (B) Mèze (18) to Tautavel (31) and (C) Rivesaltes (32) to Banyuls (38). The central zone of the $P-M$ system appears to correspond roughly to the $\mathrm{B}$ region where the frequency of infected flies is the highest.

1984. The number of values shown is much smaller, particularly in the northern region. Many samples were collected as larvae in 1984 and it must be kept in mind that the frequency of infected flies can only be determined in samples where flies have been collected as aduts. When flies are collected as larvae, they are issued from an unknown number of females and the frequency measured in the sample is not necessarily representative of that prevailing in the population. The pattern presented by the frequency values, though less clear, does not contradict the 1983 observations.
1985. The collected values, although fewer than in 1983, have a wider range-from 11 to 57 per cent-but they also appear to be distributed into three zones following the same pattern.

1986. Though less distinct, the three zones are still present and the observed values range from 20 to 57 per cent.

Over the whole period studied (table 5), the frequency of infected flies has significantly increased from 1983 to 1986 and this phenomenon occured in each of the three zones studied.

\section{DISCUSSION}

\section{The P-M system}

There is a gradual variation in the $P-M$ status within the Languedoc-Roussillon populations of D. melanogaster. The northernmost populations are weak $P$ type, the central ones $Q$ type and the southernmost $M^{\prime}$ type. 
All harbour $P$ homologous sequences, and $P$ elements capable of promoting the transposition of a white- $P$ transposon have been found in many of the $P, Q$ and $M^{\prime}$ strains of this area (D. Coen, personal communication).

Quantitative (copy number) and qualitative (element structure) differences among populations may explain the observed distribution. Differences in copy number have been found in Eurasian populations by in situ hybridization (Ronsseray, personal communication). The values range from approximately 40 copies per haploid genome in France, to approximately ten copies in Mid-Asian USSR, which parallels the previously described variation of the $P-M$ system in that area (Anxolabéhère et al., 1985).

Differences in element structure have also been described in European populations (Black et al., 1987). A $1 \cdot 15 \mathrm{~kb}$ non-autonomous $P$ element, (the $K P$ element) present in many copies (up to 30 ), has been found in many European strains. The internal deletion sustained by this $K P$ element removes all sequences homologous to the $P_{2}$ probe used in this study. Previous studies (Anxolabéhère et al., 1985) have shown that from central Europe to middle Asian USSR, the $P$ element bearing strains exhibit significantly weaker hybridization to the $P_{2}$ probe than to the $P_{1}$ probe. However, this is not seen for these French strains which almost always had equal strength of hybridization to the two probes. In the Languedoc-Roussillon populations, the observed relative homogeneity of hybridization signals hence suggests that no major differences in copy number or element structure exist among these populations. The observed pattern may thus be largely due to minor differences in the relative proportions of complete and deleted sequences. Considering the level of potential $P$ sterility, the complete elements may represent a small fraction of the total set and be slightly more frequent in the northern populations.

In European populations, variations in copy number and in relative proportions of complete and deleted elements have been interpreted as component of the ongoing phase of the invasion hypothesis of $D$. melanogaster by the $P$ element family (Anxolabéhère et al., 1985). This invasion (Kidwell, 1983) appears to be the most likely explanation of the presence of $P$ in $D$. melanogaster and its absence in other species of the melanogaster subgroup, although it has been detected in more distantly related species (review in Anxolabéhère and Periquet, 1988).

Recent genetic and molecular analyses are consistent with a world-wide invasion of $D$. melanogaster by $P$ elements, evolving over the last thirty years (Anxolabéhère et al., 1988). They suggest that the invasion of the Americas preceded the European front by about a decade and indicate that France may have been invaded by $P$ elements during the mid 1960s.

The present state and characteristics of the Languedoc-Roussillon populations initiated the discussion of the fate of this invasion in Europe. It is now well established that $P$ elements undergo internal deletions, often at a very high frequency, when introduced into an $M$ cytotype (O'Hare and Rubin, 1983; Volker etal., 1984). This phenomenon leads to populations harbouring fewer autonomous $P$ elements, thus resulting in lower $P$ potential activity. The same fate occurs in laboratory collections and has been tested in experimental populations (Anxolabéhère et al., 1986). In the model of innovative stepping-stone invasions, Anxolabéhère et al. (1986) have proposed that during the initial invasion of American populations, $P$ elements underwent this type of internal deletion leading to moderate $P$ strains. The following step was the invasion of Eurasia and resulted from the introduction of this mixture of complete and deleted elements in the first area attained (France), leading to weak $P / Q$ populations. During this process, new deleted elements appeared, which, along with rare autonomous elements, continued their spread to the East, forming the $M^{\prime}$ strains presently found from Central Europe to Middle Asia. The present distribution of the $P-M$ system in Languedoc-Roussillon and

Table 5 Increase of the frequency of flies infected by the sigma virus in samples collected between 1983 and 1986 in the Languedoc-Roussillon area and classified in three latitudinal zones. Each percentage is given with its confidence interval at 5 per cent

\begin{tabular}{llllllr}
\hline Year & $\begin{array}{l}\text { No. flies } \\
\text { tested }\end{array}$ & $\begin{array}{l}\text { North } \\
\text { (Les Fumades-Gigean) }\end{array}$ & $\begin{array}{l}\text { No. flies } \\
\text { tested }\end{array}$ & $\begin{array}{l}\text { Centre } \\
\text { (Mèze-Salses) }\end{array}$ & $\begin{array}{l}\text { No. flies } \\
\text { tested }\end{array}$ & $\begin{array}{l}\text { South } \\
\text { (Tautavel-Cerbère) }\end{array}$ \\
\hline 1983 & 367 & $8 \cdot 2 \pm 2 \cdot 8$ & 430 & $20 \cdot 2 \pm 3 \cdot 8$ & 217 & $6 \cdot 9 \pm 3 \cdot 4$ \\
1984 & 79 & $19 \cdot 0 \pm 8 \cdot 6$ & 521 & $30(01 \pm 3 \cdot 9$ & 205 & $13 \cdot 7 \pm 4 \cdot 7$ \\
1985 & 65 & $21 \cdot 5 \pm 9 \cdot 9$ & 173 & $35 \cdot 8 \pm 7 \cdot 1$ & 144 & $17 \cdot 4 \pm 6 \cdot 2$ \\
1986 & 832 & $35 \cdot 5 \pm 3 \cdot 3$ & 864 & $46 \cdot 9 \pm 3 \cdot 3$ & 295 & $25 \cdot 8 \pm 5 \cdot 0$ \\
\hline
\end{tabular}



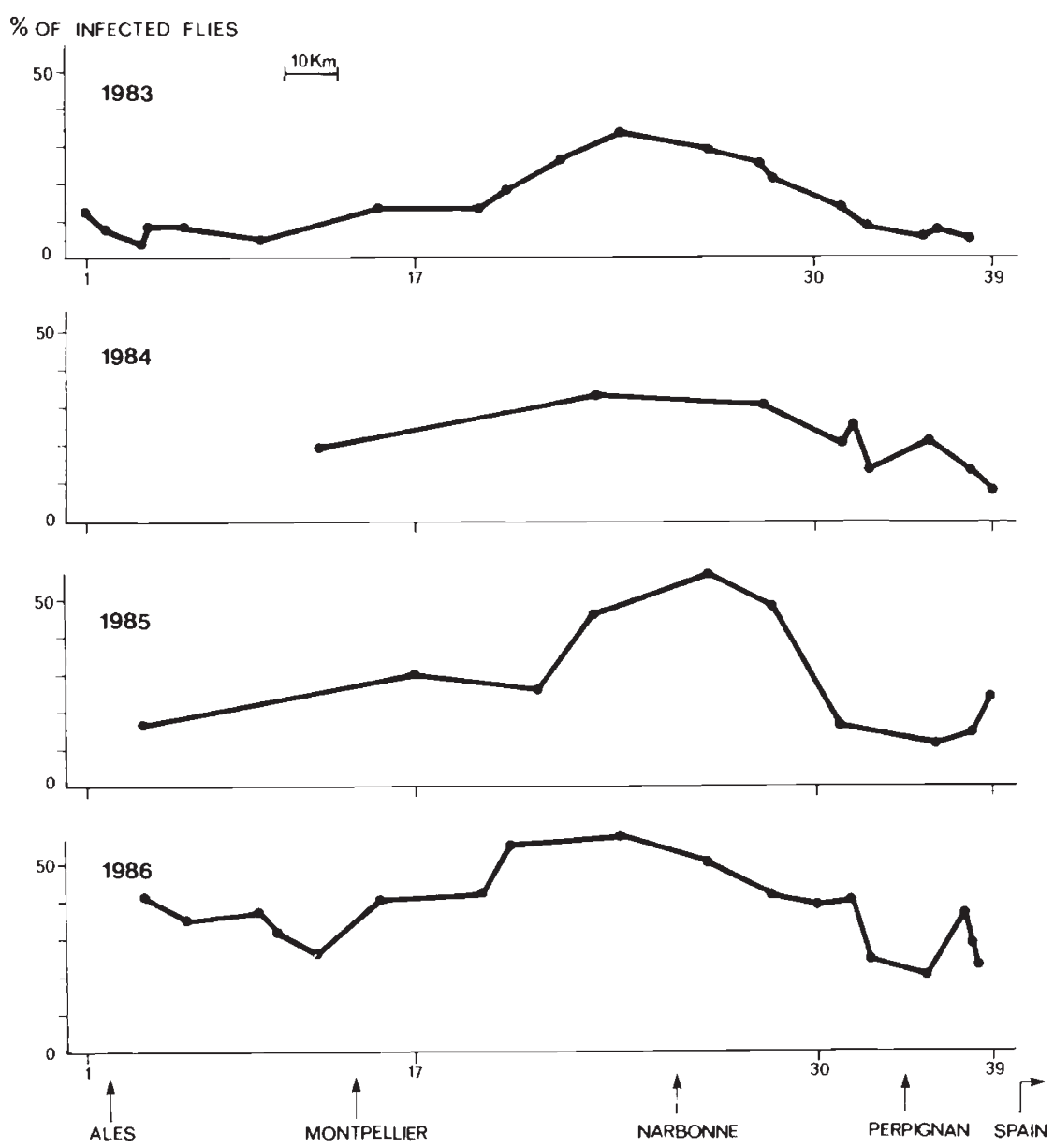

Figure 4 Geographical and temporal distributions of strains collected in Languedoc-Roussillon according to their frequency of infection by the sigma virus.

more generally in Europe reflects this process. One possible outcome might be the continuation of the invasion process with slow modifications of European strains, leading to a general state in which all populations would be of the $Q$ type. However, mixed population experiments have shown that when weak $P / Q$ strains were mixed with $M^{\prime}$ strains, the $P$ potential activity slowly decreased to an almost zero level, whereas the $M$ cytotype did not always decrease to such an extent and sometimes did not totally disappear even after 30 generations (Anxolabéhère et al., 1986). In the wild, the presence of numerous deleted elements, some presenting a regulatory role in suppressing $P$ activity and dysgenic traits in their carrier (Black et al., 1987), might intervene to slow down the transformation of the populations. In this case, an alternative evolutionary fate would be the maintenance of a quasi-stable equilibrium in the distribu- tion of $P$ sequences among populations, leading to a world-wide differentiation between $P / Q$ and $M^{\prime}$ populations similar to the situation presently observed in Languedoc-Roussillon, in Europe and in Australia (Boussy and Kidwell, 1987). Further analysis is needed to test these evolutionary hypotheses.

\section{Enzymatic polymorphism}

At the six loci studied, different levels of variability were shown but in spite of these differences, the patterns of allele frequency distribution are similar within the different populations and no geographical structurations have been found. Moreover, the comparison between this data and that obtained in other natural French populations (Girard and Palabost, 1976; Charles-Palabost et al., 1985) shows a remarkable similarity in the 
mean frequencies at the most common allele of the loci analyzed (table 4). For these loci, it seems that the temperate habitats in France do not vary sufficiently to provide much genetic differentiation. Nevertheless, it must be noted that this differentiation appears when more distant European populations are studied, suggesting that allelic frequencies at the Adh, Est-6, $\alpha-G p d h$ and Pgm loci are correlated to latitude (Oakeshott et al., 1983).

Concerning variations in time, in the Languedoc-Roussillon, the Mèze population was sampled and analyzed in 1973, 1974 and 1983 and no significant trends were found in the genetic structure of this population (Charles-Palabost et al., 1985). As the Mèze population is the only one that has been followed over time in the Languedoc-Roussillon area, it is difficult to extrapolate these results to the entire area. However, other surveys of French populations analyzed over different periods of time have also shown homogeneity with no major changes during the five to ten years considered (Girard and Palabost, 1976; Charles-Palabost et al., 1986).

In conclusion, it is clear that for the LanguedocRoussillon area, neither geographic nor temporal distributions of the allelic frequencies at the enzymatic loci analyzed showed variations similar to and correlated with those found in the $P-M$ and the Drosophila-sigma systems.

\section{Drosophila-sigma system}

The frequency of infected flies follows a very regular pattern, with values increasing steadily from the north to a central zone (Narbonne) and then decreasing towards the south. It may be noted that the altitude of the region increases towards the north (Massif Central) and towards the south (Pyrenees). It has been shown previously (Fleuriet, 1981) that infected flies might be more sensitive to winter. However, taken alone, the differences in altitude, ranging from 0 to $200 \mathrm{~m}$, do not seem large enough to lead to such differences in frequency.

A few loci (called ref) of the fly are known to confer resistance to the virus (Gay, 1978). Two viral types have been described and the Viral Type II is the most resistant to the effect of the $\operatorname{ref}(2)$ $P$ locus (Fleuriet, 1986). It is interesting to note (Fleuriet et al., in preparation) that the frequency of Viral Type II seems to be higher in the median zone. This type is the most efficiently transmitted, first because of its greater resistance to the ref (2) $P$ locus, and also because of its higher transmission by males in Languedoc-Roussillon. This might account, at least in part, for the higher frequency of infected flies in the central area. However, at the present time, no interpretation of the high frequency of Type II there is possible. Moreover, the frequency of Viral Type II has also been observed to increase in Languedoc-Roussillon from 1983 to 1986 . This might account, at least in part, for the increase in frequency of infected flies observed during the four years of this study.

\section{Correlations between the different systems}

In these results, the enzymatic polymorphism, for the six loci observed, appears to behave independently of the other systems. However, a striking correlation occurs between the distribution of the sigma-infected flies frequency and the $P-M$ status of the Languedoc-Roussillon populations. The highest frequency of infected flies is encountered in the central zone where the populations are of the $Q$ type (with a $P$ cytotype and the lowest $P$ potential activity). Although unexpected, this correlation has been maintained over the four year period analyzed. It might result from the effect of a unique environmental factor, structuring this region and acting independently upon both systems. Conversely, it might correspond to a more significant biological relationship (e.g., at the level of the germ line), the analysis of which would be of special interest.

Acknowledgements We thank M. H. Hamelin, J. C. Landré, M. Lehmann and D. Nouaud for their technical assistance, the directors and the personnel of the Coop wine cellars for their cordial welcome and $\mathrm{Ph}$. L'Héritier for his helpful comments. This work was supported by grants from the Centre National de la Recherche Scientifique (UA 340, UA 360, UA 693, GRECO 44, ATP Invasion), the Mission de la Recherche de l'Education Nationale (ARU 85-86) and the E. and V. Hasselblad foundation.

\section{REFERENCES}

ANXOLABÉHÈre, D. AND PERIQUET, G. 1988. $P$ homologous sequences in Diptera are not restricted to the drosophilidae family. Genet. Iber., (in press).

ANXOlABÉhère, D., NOUAUD, D. AND PERIQUET, G. 1982. Etude de la variabilité du système $P-M$ de dysgénésie des hybrides entre populations de Drosophila melangoaster. $C$. R. Acad. Sc. Paris., 294, 913-918.

ANXOLABÉHÈrE, D. HU KAI, NOUAUD, D., PERIQUET, G. AND RONSSERAY, S. 1984 The geographical distribution of $P-M$ hybrid dysgenesis in Drosophila melanogaster. Génét. Sél Evol. 16, 15-26.

ANXolabéhère, D., Nouaud, D., Periquet, G. AND TCHEN, P. 1985. P-element distribution in Eurasian populations of Drosophila melanogaster: a genetic and molecular analysis. Proc. Natl. Acad. Sci. USA, 85, 5418-5422. 
ANXOlabÉHÈre, D., NOUAUd, D., PERIQUET, G. AND RONSSERAY, S. 1986. Evolution des potentialités dysgénésiques du système $P-M$ dans des populations expérimentales mixtes $P, Q, M$ et $M^{\prime}$ de Drosophila melanogaster. Genetica, 69, 81-95.

ANXOLABÉHÈRE, D., KIDWELL, M. G. AND PERIQUET, G. 1988. Molecular characteristics of diverse populations are consistent with a recent invasion of Drosophila melanogaster by mobile $P$ elements. Molec. Biol. Evol., (in press).

BINGHAM, P. M., KIDWELL, M. G. AND RUBIN, G. M. 1982. The molecular basis of the $P-M$ hybrid dysgenesis: The role of the $P$ element, a $P$ strain transposon family. Cell, 29, 995-1004

BLACK, D. M., JACKSON, M. S., KIDWELL, M. G. AND DOVER, G. A. 1987. $K P$ elements repress $P$-induced hybrid dysgenesis in D. melanogaster. EMBO journal, 6, 4113-4123.

BOUSSY, 1. A. AND KIDWELL, M. G. 1987. The $P-M$ hybrid dysgenesis cline in Eastern Australian Drosophila melanogaster: discrete $P, Q$, and $M$ regions are nearly contiguous. Genetica, 115, 737-795.

BREGLIANO, J. C. AND KIDWELL, M. G. 1983 . Hybrid dysgenesis determinants. In Shapiro, J. A. (ed.) Mobile Genetic elements, Academic Press, New York. pp. 363-410.

BRUN, G. AND PLUS, N. 1980. The viruses of Drosophila. In Ashburner, M. and Wright, T. R. F. (eds) The Genetics and Biology of Drosophila, Academic Press, New York, pp. 626-702.

CHARLES-PALABOST, L., LEHMANN, M. AND MERÇOT, H. 1985. Allozyme variation in fourteen natural populations of Drosophila melanogaster collected from different regions of France. Génét. Sél. Evol., 17, 201-210.

CHARLES-PALABOST, L., MERÇOT, H. AND GIRARD, P. 1986. Stabilité du polymorphisme électrophorétique de douze populations naturelles françaises de $D$. melanogaster. Entomol. Exp. appl., 42, 145-149.

ENGLES, W. R. 1979. Hybrid dysgenesis in Drosophila melanogaster: rules of inheritance of female sterility. Genet. Res. Camb., 33, 219-236.

ENGELS, W. R. 1983 . The $P$ family of transposable elements in Drosophila. Ann. Rev. Genet., 17, 315-344.

ENGELS, W. R. AND PRESTON, C. 1980. Components of hybrid dysgenesis in a wild population of Drosophila melanogaster. Genetics, 95, 111-128.

FLEURIET, A. 1981. Effect of overwintering on the frequency of flies infected by the Rhabdovirus sigma in experimental populations of Drosophila melanogaster. Arch. virol., 69, 2530.
FLEURIET, A. 1986. Perpetuation of the hereditary sigma virus in populations of its host, D. melanogaster. Geographical analysis of correlated polymorphisme. Genetica, 70, 167177.

GAY, P. 1978. Les gènes de la drosophile qui interviennent dans la multiplication du virus sigma. Mol. Gen. Genet., 159, 269-283.

GIRARD, P. AND PALABOST, L. 1976. Etude des polymorphismes enzymatiques de 15 populations naturelles de Drosophila melanogaster. Arch. Zool. Exp. Gén., 117, 41-55.

KARESS, R. E. AND RUBIN, G. M. 1984. Analysis of $P$ transposable element functions in Drosophila. Cell, 38, 135-146.

KIDWELL, M. G. 1983. Evolution of hybrid dysgenesis determinants in Drosphila melanogaster. Proc. Natl. Acad. Sci. USA, 80, 1655-1659.

KIDWEll, M. G. 1985. Hybrid dysgenesis in Drosphila melanogaster: nature and inheritance of $P$ element regulation. Genetics, 111, 337-350.

L'HÉRITIER, PH. 1970. Drosophila viruses and their role as evolutionary factors. Evol. Biol., 4, 185-209.

OAKESHOTT, J. B., GIBSON, J. B., WILLCOCKS, D. A. AND CHAMBERS, G. D. 1983. Latitudinal variation in octanol dehydrogenase and acid phosphatase allele frequencies in Drosphila melanogaster. Theor. Appl. Genet., 65, 191-196.

O'HARE, K. AND RUBIN, G. M. 1983. Structures of $\boldsymbol{P}$ transposable elements and their sites of insertion and excision in the Drosphila melanogaster genome. Cell, 34, 25-35.

PERIQUET, G. 1980. "Atrophie gonadique" character and hybrid dysgenesis in Drosphila melanogaster. Biol. Cell., $39,7-12$.

PLUS, N. 1954. Etude de la multiplication du virus de la sensibilité au gaz carbonique chez la drosophile. Bull. Soc. Biol. Fr. Belg., 88, 1-46.

SIMMONS, G. M. AND BUCHOLZ, L. M. 1985. Transposase titration in Drosphila melanogaster: a model for cytotype in the $P-M$ system of hybrid dysgenesis. Proc. Natl. Acad. Sci. USA, 82, 8119-8123.

TCHEN, P., ANXOLABÉHÈRE, D., NOUAUD, D. AND PERIQUET, G. 1985. Hybridization on squashed flies: a method to detect gene sequences in individual drosophila. Anal. Biochem., 150, 425-420.

VOELKER, R. A., GREENLEAF, A., GYURKOVICS, H., WISELY, G., HUANG, S. AND SEARLES, L., 1984. Frequent imprecise excision among reversions of a $P$ element-caused lethal mutation in Drosophila. Genetics, 107, 279-294. 